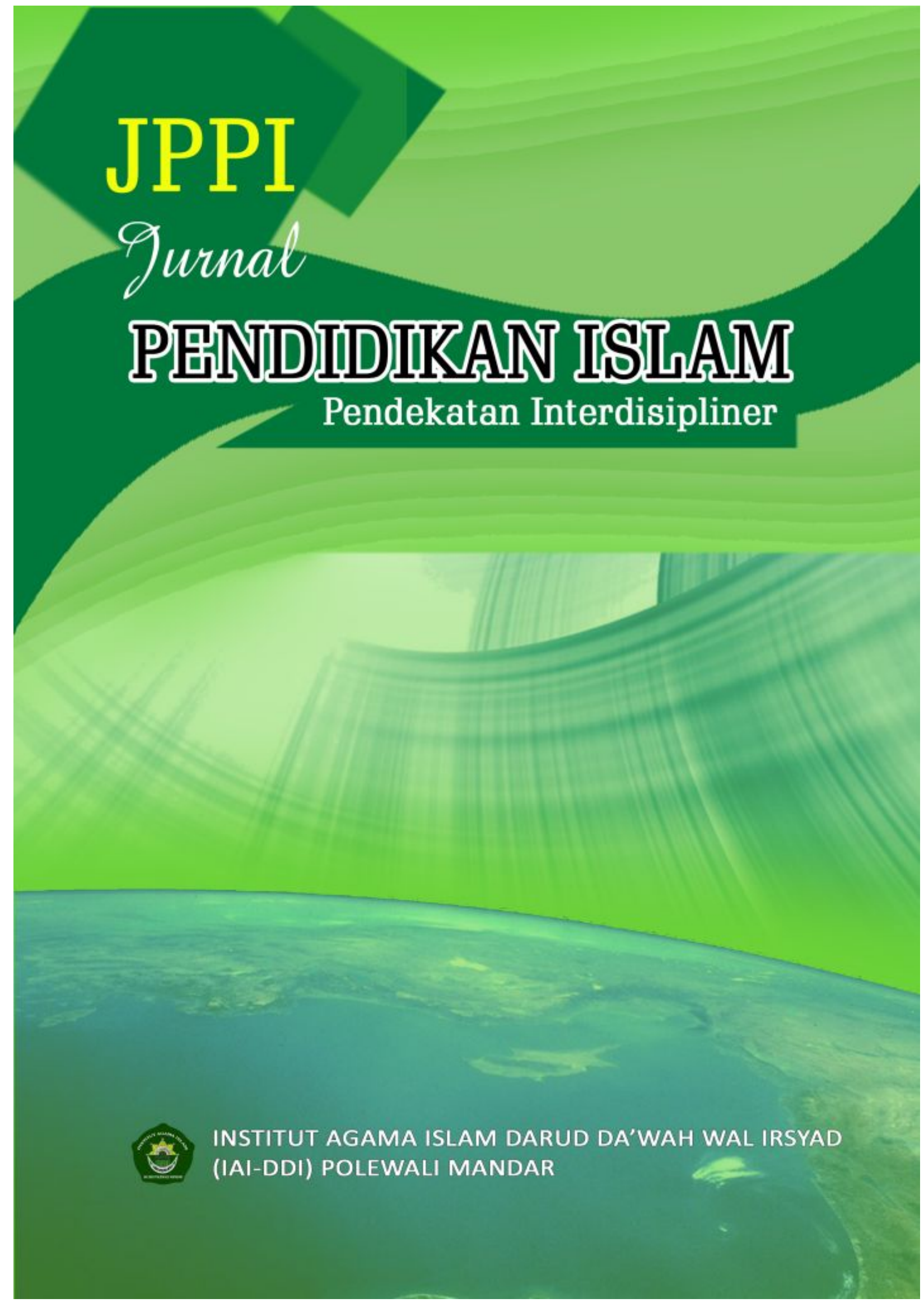




\title{
PELATIHAN PENGEMBANGAN PEMBELAJARAN BERBASIS BLENDED LEARNING PADA SMK PP NEGERI REA TIMUR
}

\author{
Syaifullah NS, SE, M.Adm.KP \\ SMK PP Negeri Rea Timur \\ Email : syaifullahkwu@gmail.com
}

\begin{abstract}
Abstrak: Pengembangan pembelajaran berbasis blended learning ini bertujuan untuk memfasilitasi terjadinya belajar bagi peserta didik, sekaligus memberikan bekal ilmu pengetahuan dan teknologi tentang bagaimana koneksitas diri sistem google education. Perangkat lunak yang digunakan sebagai media pembelajaran adalah perangkat lunak LMS (Learning Management System) Classroom Google atau Google Kelas. Sedangkan peserta pelatihan merupakan Siswa Siswi SMK PP Negeri Rea Timur. Pemberian materi dimulai dari pengenalan internet, website dan proses aktivasi akun berbasis Google Edu dengan kapasitas tidak tak terhingga (Unlimeted). Materi diakhiri dengan memberikan tugas mandiri bagi masing-masing peserta untuk membuat dan mengembangkan sendiri disesuaikan dengan bidang ajar peserta. Dari peserta dengan jumlah guru , siswa dan siswi, semuanya dapat mengikuti pelatihan dari awal sampai akhir. Selain itu, kesemua guru dapat menyelesaikan tugas mandiri dengan baik, yaitu mampu membuat dan mengembangkan google classroom beserta kontennya.
\end{abstract}

Kata Kunci: blended learning, pengembangan konten, pembelajaran online

Paradigma saat ini adalah perubahan pola belajar peserta didik, dari mono tasking menjadi pola multi tasking. Semua dipengaruhi adanya perubahan peradaban, dari peradaban teknologi perkembang menjadi teknologi modern. Perkembangan teknologi ini, sangat mempengaruhi kebutuhan akan suatu konsep dan mekanisme belajar mengajar berbasis Teknologi
Iinformasi menjadi tidak terelakkan lagi. Kelas maya semakin berkembang pula, bahkan perkembangannya semakin bervariatif dengan keunggulan dan kelemahannya masing-masing, seperti moodle, claroline, edmodo, dan salah satunya yang akan dikembangkan dalam hal ini adalah google kelas atau classroom google. Kelas Maya adalah sebuah media Halaman 86 
pembelajaran yang memungkinkan sistemnya

bekerja dengan baik dan menjalankan fungsi pengajaran di kelas meski tanpa kehadiran dosen atau guru secara langsung, dan konsep ini lebih dikenal dengan sebutan e-learning. Hal ini membawa pengaruh terjadinya proses transformasi pendidikan konvensional ke dalam bentuk digital, baik secara isi (contents) dan sistemnya. e-learning adalah suatu jenis belajar mengajar yang memungkinkan tersampaikannya bahan ajar ke siswa dengan menggunakan media internet, intranet atau media jaringan komputer lain. Saat ini konsep e-learning sudah banyak diterima oleh masyarakat dunia, terbukti dengan maraknya implementasi e-learning di lembaga pendidikan (sekolah, training dan univer sitas) maupun industri (Hartley, 2001). Bila dikaji secara mendalam inti dari tujuan pendidikan, maka prinsipnya adalah mengem bangkan tiga aspek utama yaitu aspek pe ngetahuan, aspek sikap, dan aspek keteram pilan. Dalam dunia pendidikan, bila dihu bungkan dengan tuntunan lapangan kerja selalu menjadi masalah yang kompleks, se bab di satu sisi pendidikan itu berjalan me nurut dinamikanya, sementara lapangan kerja menghendaki perubahan maupun keteram pilan.

Penggunaan teknologi yang kompre hensif aspek, alat dan metode terintegrasi dengan alat-alat software atau perangkat lunak serta hardware atau perangkat keras untuk memecahkan masalah pendidikan baik makro maupun mikro adalah sangat ideal (Rumpar, 1987). Dengan demikian penerapan teknologi pendidikan mempunyai arti besar dalam upaya meningkatkan mutu pendidikan. Tidak ada alternatif lain kecuali meman faatkan jasa teknologi dalam dunia pendi dikan.

Berdasarkan pemaparan di atas system e-learning sebagai salah satu konsep pembe lajaran yang dinilai efektif dan efisien dalam rangka pemanfaatan teknologi informasi untuk dunia pendidikan telah dinilai perlu untuk mengantisipasi perkembangan jaman di mana semua menuju era digital baik mekanisme maupun konten

Pengembangan system e-learning ini harus didahului dengan melakukan analisa 
terhadap kebutuhan dari pengguna (user needs).

Lahir dan berkembangnya e-learning dalam dunia pendidikan diharapkan mampu meningkatkan efektivitas dan efisiensi seka ligus mengatasi tiga masalah besar pendi dikan khususnya di Indonesia sebagaimana ditulis dalam Rencana Strategi (Renstra) Pendidikan Nasional 2005-2009, yaitu (1) pemerataan dan akses pendidikan, (2) mutu, relevansi dan daya saing lulusan, dan (3) tata kelola atau governance, akuntabilitas dan citra publik terhadap pendidikan.

Pemanfaatan e-learning sangat diperlukan dalam membangun sektor pendidikan di Indo nesia, khususnya berkaitan dengan masalah pemerataan dan akses pendidikan.

Sesuai dengan perkembangan sistem dan perangkat lunak, kebutuhan dari pengguna ini memiliki kedudukan yang tertinggi dan merupakan implementasi dari system elearning yang sebagian besar diakibatkan bahwa sistem yang dikembangkan tidak sesuai dengan apa yang sebenarnya dibutuhkan oleh pengguna. Maka selanjutnya e-learning ini kemudian berevolusi dengan lahirnya m- learning yang mana lebih menekankan pada pola pengaksesan kontent dari perangkat mobile seperti PDA, handphone, smartphone ataupun tablet. M-learning atau mobile lear ning merupakan konsep pembelajaran secara mobile menggunakan perangkat mobile seperti PDA (Personal Digital Assistance) dan telepon selular yang memungkinkan adanya pembelajaran “kapanpun di manapun” (Krämer 2005).

Moodle (Modular Object-Oriented Dyna mic Learning Environment) adalah sebuah CMS (Course Management System) yang merupakan software Open Source yang dikembangkan untuk membantu para pendi dik (educators) membuat sebuah pembela jaran online yang efektif (www.moodle.org). Moodle merupakan salah satu aplikasi dari konsep dan mekanisme belajar mengajar yang memanfaatkan teknologi informasi. Moodle adalah sebuah nama untuk sebuah program aplikasi yang dapat merubah sebuah media pembelajaran ke dalam bentuk web. Kelebihan lain dari moodle adalah sifatnya yang open source, yaitu suatu aplikasi gratis yang dapat dikembangkan sendiri oleh 
pemakai.

Mobile learning Engine (MLE) adalah aplikasi pembelajaran yang komprehensif. Dia mengkonversi model Pembelajaran yang menggunakan komputer dan berbasis mul timedia (dikenal sebagai e-Learning) ke lingkungan mobile (ke telepon selular). Sistem pembelajaran yang menggunakan komputer dan multimedia based dipadukan dengan perangkat mobile dikenal sebagai "mLearning". MLE adalah aplikasi pertama yang bisa digunakan untuk mendesain model pembelajaran mobile untuk ponsel dan dikembangkan sejak tahun 2003. (http://mle.sourceforge.net).

Dari uraian di atas, maka dapat dirumuskan beberapa permasalahan yang akan dipecahkan pada program kegiatan ini, yaitu:

1. Bagaimanakah mengembangkan sebuah e- learning beserta pengembangan konten nya dengan menggunakan perangkat lunak open source?

2. Bagaimanakah proses melakukan manaje men pembelajaran atau course manage ment sesuai dengan mata pelajaran yang diampu oleh peserta pelatihan?

Sasaran dari kegiatan ini secara langsung adalah guru-guru dan siswa SMK PP Negeri Rea Timur. Sedangkan efek domino yang diharapkan dari kegiatan ini adalah 1) terciptanya suatu sistem e-learning yang dapat digunakan oleh guru dan siswa sebagai salah satu usaha peningkatan kualitas pembelajaran, 2) guru-guru peserta pelatihan dapat menularkan ilmu yang sudah didapatkan kepada guru-guru lainnya, sehingga tercipta sebuah sistem $e$ - learning yang dapat menampung berbagai macam materi mata pelajaran.

Metode yang digunakan pada kegiatan ini dapat diperinci sesuai dengan tabel berikut: 
JPPI (Jurnal Pendidikan Islam Pendekatan Interdisipliner

Vol 3 No 1 (2019)

\begin{tabular}{|c|l|l|} 
No & \multicolumn{1}{|c|}{ Materi } & \multicolumn{1}{|c|}{ Metode Kegiatan } \\
\hline 1. & Kuisiner awal & tes individu \\
\hline 2. & $\begin{array}{l}\text { Pengantar tentang sistem pembelajaran (model } \\
\text { tradisional versus model elektronik) }\end{array}$ & ceramah, diskusi \\
\hline 3. & Pengantar tentang Internet dan Website & ceramah, diskusi \\
\hline 4. & Pemahaman software open source & ceramah, diskusi \\
\hline 5. & Instalasi server web & tutorial, praktik \\
\hline 6. & Instalasi program aplikasi e-learning & tutorial, praktik \\
\hline 7. & Setting course & tutorial, praktik \\
\hline 8. & Upload file course & tutorial, praktik \\
\hline 9. & Mengelola aktifitas course & tutorial, praktik \\
\hline 10. & Manajemen peserta didik & tutorial, praktik \\
\hline 11. & Pengaturan tampilan E-Leaming & tutorial, praktik \\
\hline 12. & Proses upload e-learning & tutorial, praktik \\
\hline 13. & Review materi & diskusi, tanya jawab \\
\hline 14. & Penyiapan materi ajar & Tugas \\
\hline 15. & $\begin{array}{l}\text { Tugas mandiri membuat dan melakukan } \\
\text { manajemen content pada e-learning sesuai } \\
\text { mata pelajaran yang diampu oleh masing- } \\
\text { masing peserta }\end{array}$ & Tugas \\
\hline 16. & $\begin{array}{l}\text { Pendampingan bagi yang memerlukan } \\
\text { konsultasi }\end{array}$ & diskusi, tanya jawab \\
\hline
\end{tabular}

Evaluasi yang akan dilakukan terkait

dalam kegiatan ini ada dua macam, yaitu:

a. Kuisiner awal (Survey)

Survey diberikan kepada para peserta untuk mengetahui kemampuan awal, terutama pemahaman dan pengetahuan tentang Internet dan Website secara umum. Hasil evaluasi, digunakan untuk mengetahui posisi awal pemberian materi agar materi yang disampaikan bisa sesuai dengan kemampuan awal peserta.

b. Evaluasi di akhir kegiatan (Postest)

Untuk evaluasi di akhir kegiatan, dilakukan untuk mengetahui kemam puan dan ketrampilan peserta selama pelatihan.

Evaluasi ini terdiri dari dua macam, yaitu evaluasi disisi kemampuan pembuatan e-learning dan evaluasi tentang isi atau content dari e-learning yang telah dibuat. 
Indikator keberhasilan dari kegiatan ini ditandai dengan:

- Peserta pelatihan mempunyai pemahaman tentang sistem pembelajaran elektronik

- Peserta pelatihan mempunyai pemahaman tentang software berbasis open source moodle.

- Peserta pelatihan mampu untuk melakukan instalasi server web dan instalasi program e- learning.

- Peserta pelatihan mampu untuk melakukan setting course, upload file course, mengelola aktifitas course dan manajemen peserta didik dari $e$ learning yang dibangun sesuai dengan mata pelajaran yang diampu.

- Peserta pelatihan mampu melakukan proses upload e-learning

- Peserta pelatihan mampu membuat dan me- lakukan manajemen content pada e-learning sesuai dengan mata pelajaran yang diampu.

\section{Faktor Pendukung dan Penghambat}

Faktor pendukung dan faktor pengham bat dalam kegiatan pelatihan pembuatan $e$ learning dan pengembangan konten bagi guru-guru dan siswa SMK persada dan Bajiminasa Makassar ini adalah sebagai berikut:

1. Faktor Pendukung

- Peserta adalah Guru dan Siswa dari jurusan Teknik Komputer dan Jaringan sehingga relatif sudah memiliki kemampuan dalam meng gunakan teknologi informasi sebagai media pembelajaran.

- Semangat para peserta dalam mengikuti pelatihan dari awal sampai akhir didukung oleh kemampuan dasar penggunaan komputer yang cukup baik dari peserta.

2. Faktor Penghambat

- Rata-rata guru belum memiliki bahan ajar digital sehingga belum bisa menyelesaikan konten secara maksi 
mal.

- Komputer dan laptop untuk works hop sangat terbatas sehingga kegiatan workshop belum maksimal karena hanya bisa menggunakan sebuah laptop untuk 3 orang.

- Pada saat proses pengerjaan tugas mandiri, kemampuan para peserta ber variasi, sehingga terdapat peserta yang cepat dalam menyelesaikan pembuatan media pembelajaran dan ada yang lambat. Hal ini bisa diatasi dengan bimbingan yang lebih intensif bagi peserta yang kurang cepat dalam penyelesaian tugas mandiri.

\section{PELAKSANAAN KEGIATAN}

Peserta pelatihan adalah guru-guru beserta siswa SMK PP Negeri Rea Timur Polewali Mandar. Guru dan siswa yang diundang dalam pelatihan ini yang diharapkan kelak menjadi percontohan dalam penerapan E-Learning dan MLearning di Kabupaten Polewali Mandar Vol 3 No 1 (2019): JPPI Volume 3 Nomor 1 Juni 2019
Provinsi Sulawesi Barat

Dari segi materi, telah disiapkan materi yang terkait dengan pelatihan e-learning, yaitu diantaranya:

1. Materi Pengenalan e-learning (dalam format powerpoint)

2. Materi Tutorial E-Learning MOODLE (dalam bentuk tutorial pdf)

3. Materi Pembuatan kuiz di MOODLE (dalam bentuk pdf)

4. File pendukung server (xampp)

5. File pendukung E-Learning Moodle

6. File pendukung materi-materi dalam format gambar, animasi, powerpoint, pdf.

Tugas mandiri diberikan pada para peserta pelatihan untuk membuat materi ajar digital beserta manajemen kontennya sesuai dengan mata pelajaran yang diampu pada sekolahnya masing-masing bagi guru, sementara untuk siswa ditugaskan untuk membangun sistema e- learning mulai dari instalasi server, moodle dan manajemen e-learningnya. 


\section{Pembahasan Hasil Pelaksanaan Kegiatan}

Pengabdian Pada Masyarakat

Secara keseluruhan hasil kegiatan pelatihan e-learning dan pengembangan konten ini berlangsung dengan baik, karena telah sesuai dengan rencana pada proposal yang diajukan. Dari jumlah total peserta baik guru maupun siswa yang mengikuti pelatihan sebanyak 30 orang. Prosentase peserta pelatihan yang berasal dari Guru 50 \% (15 orang), sedangkan yang berasal dari Siswa 50 \% (15 orang).

Kehadiran peserta pada pelatihan yang berlangsung selama 2 hari menunjukkan hasil yang bagus, dimana $99 \%$ peserta hadir dan mengikuti kegiatan pelatihan ini setiap harinya (lihat lampiran daftar hadir kegiatan pelatihan).

Dalam proses kegiatan pelatihan, setiap tiga orang peserta dibekali 1 perangkat laptop dengan spesifikasi multimedia yang juga terhubung ke server e-learning yang disiapkan oleh tim workshop menggunakan jaringan via access point wireless. Dengan pola ini, maka diharapkan peserta untuk belajar sambil melakukan (learning by doing). Penyampaian materi pelatihan dilakukan dengan bantuan LCD Proyektor, sehingga proses komunikasi dapat berlang sung dengan baik, terutama pada saat penyampaian materi yang berupa tutorial step-by-step.

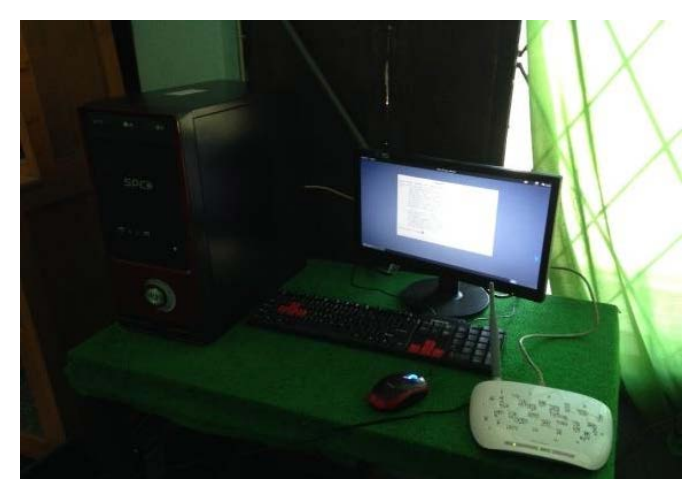

Proses evaluasi akhir dilakukan dengan memberikan tugas mandiri kepada peserta untuk membuat e-learning beserta pengem bangan kontennya. E-learning yang dibuat disesuaikan dengan bidang keahlian masingmasing peserta. Pada proses pengerjaan tugas mandiri, dilakukan proses pendampingan oleh instruktur kepada peserta. Bagi peserta yang merasa kesulitan dan membutuhkan bim bingan tentang segala sesuatu yang berkaitan dengan pengerjaan tugas mandiri diper Halaman 93 
bolehkan untuk melakukan konsultasi dengan

instruktur pelatihan. Hasil dari tugas mandiri ini menjadi acuan bahwa peserta telah menguasai kompetensi yang diajarkan pada saat pelatihan.

Dari hasil tugas mandiri, didapatkan hasil yang baik, dimana semua peserta dapat menyelesaikan pembuatan e-learning dan pengembangan konten sesuai dengan kompetensi yang dajarkan pada saat pela tihan. Yang membedakan antara hasil satu peserta dengan hasil dari peserta lainnya adalah waktu pengerjaan, dimana ada bebe rapa peserta yang cepat menyelesaikan pengerjaan tugas mandiri, dan ada pula yang relatif lebih lama.

Kegiatan pelatihan dan workshop dalam kegiatan pengabdian masyarakat ini adalah :

1. Kegiatan kunjungan awal dan persiapan pelaksanan pengabdian.Kegiatan yaitu berupa kegiatan kunjungan ke sekolah mitra untuk membicarakan beberapa hal teknis terkait pelaksanaan pelatihan dan workshop e-learning bagi guru dan siswa serta penerapannya.

2. Pelatihan dan Workshop Implementasi E-learning moddle. Tujuan dari pela tihan dan workshop implementasi Elearning moddle ini adalah untuk memberikan pengenalan kepada mitra baik itu guru-guru maupun siswa mengenai manfaat dan kelebihan dari sistem e-learning untuk meningkatkan mutu pendidikan disekolah mereka

3. Instalasi server Debian dan Moodle ELearning. Untuk menerapkan ELearning pada SMK PP Negeri Rea Timur, maka harus diawali dengan melakukan instalasi server, kemudian Instalasi jaringan lokal dalam area sekolah.

\section{Simpulan}

- Peserta pelatihan adalah guru-guru dan siwa SMK PP Negeri Rea Timur berjumlah 30 orang. Prosentase peserta pelatihan yang berasal dari Guru-guru 
sebesar 50 \% (15 orang), sedangkan yang berasal dari siswa-siswi sebesar 50 $\%$ (15 orang).

- Prosentase kehadiran peserta pelatihan mencapai 99\% yang menunjukkan antu siasme peserta dalam mendapatkan bekal pengetahuan khususnya dalam hal pembuatan e-learning dan pengemba ngan konten.

- Dari hasil evaluasi yang berupa tugas mandiri, didapatkan hasil yang baik, dimana semua peserta (100\%) dapat menyelesaikan tugas mandiri, meskipun lama pengerjaan yang berbeda-beda untuk setiap peserta.

\section{Saran}

- Perlu dilaksanakan kegiatan pelatihan $e$ learning khususnya dalam pembuatan materi ajar digital yang lebih menarik seperti menggunakan macromedia flash dan wondershare quiz creator untuk sistem quiznya.

- Perlu dilaksanakan pelatihan e-learning dengan materi yang mengkombinasikan pembuatan animasi untuk bisa menggambarkan materi-materi yang bersifat abstrak.

\section{DAFTAR RUJUKAN}

Anonim. Elearning. Diakses: http://id.wikipedia.org/wiki/e-learning pada 14 Januari 2013.

Anwas, O. M. (2003). "Model Inovasi elearning dalam Meningkatkan Mutu Pendidikan.”Jurnal Teknodik. Edisi No.12/- VII/Oktober/2003. (Tersedia di http://.wwwpustekkom.go.id/ teknodik/t12/isi.ht m, diunduh tanggal 11 Januari 2013

Asep Herman Suyanto. 2005. Mengenal elearning. Tersedia http://www.asephs. web.ugm.ac.id, diunduh 11 Januari 2013.

Goh, (2009) Multiplatform E-Learning Systems and Technologies: Mobile Devices for Ubiquitous ICT-Based Education. New York: Information science reference 
Herman Dwi Surjono. 2005. Pengembangan e-learning dengan Moodle. Tersadia di http://herman.elearning- jogja.org, diunduh 11 Januari 2013.

Kramer Bernd J. (2005). Mobile Learning: The Next Generation of Learning Fern-Universität's Contributions to the 2nd Year of the Leonardo Project mlearn2. FernUniversität Hagen, Germany.

Melfachrozi M. 2003. Penggunaan Aplikasi e-learning(moodle) http://ilmukom puter.com,Diunduh 11 Januari 2013.

Riyanto B, Tamimuddin M, Widayati S (2006). Perancangan Aplikasi Mlearning Berbasis Java Prosiding Konferensi Nasional Teknologi Informasi \& Komunikasi untuk Indonesia; Bandung, 3-6 Mei 2006.

Romi Satria Wahono. 2003(a). Pengantar elearning dan Pengembangannya http://ilmukomputer.com, diunduh 14 Januari 2013 . 2003(b). Sistem e-learning Berbasis Model Motivasi Komunitas. http://ilmukom- puter.com, diunduh 14 Januari 2013 2003(c). Strategi Baru Pengelolaan situs e learning Gratis. http://ilmukomputer.com, diunduh 14 Januari 2013.

Wood, Karen, (2003). Introduction to Mobile Learning (M Learning), Ferl, Becta (British Educational Communications and Technology Agency),.

http://ferl.becta.org.uk/display.cfm?pa ge $=65 \& c \quad$ atid $=192 \&$ resid $=5194$ Diakses tanggal 22 Januari 2014 ) 
